\title{
Investigation of phenol adsorption on macroporous polymeric adsorbents
}

\begin{abstract}
This work reports results on phenol adsorption from aqueous solution by porous copolymers based on glycidyl methacrylate: two samples of macroporous crosslinked poly(glycidyl methacrylate-co-ethylene glycol dimethacrylate), were synthetized by suspension copolymerisation with ethylene glycol dimethacrylate. In addition, the two copolymer samples were functionalized with ethylene diamine. The amounts of adsorbed phenol were presented in the form of adsorptions isotherms, which were interpreted using Langmuir, Freundlich and Sips' equations. The first was found to express high level of agreement with experimental data. Phenol adsorption indicate the homogeneous distribution of active sites present on the investigated polymers. It was found that adsorption of phenol on copolymers is fast and depends on the presence of amino groups and on the pore size. From the obtained results, it was possible to distinguish macroporous polymer as a material which possesses the capacity for adsorption of phenol comparable to that of activated carbon.
\end{abstract}

Keywords: phenol, adsorption, macroporous polymers, kinetics, capacity

\section{INTRODUCTION}

Phenol is present in wastewaters of various industries, such as refineries, coal processing, pharmaceuticals, plastics, wood products, paint and paper industries [1]. Therefore, wastewater is containing phenols present a serious disposal problem. Excessive exposure to phenol may cause health effects on brain, digestive system, eyes, lungs, skin and it can cause genetic damage. The effective removal of phenol from wastewaters is a problem of great importance and interest, particularly because phenol is toxic even at low concentrations. A number of references [2-4] can be found in the literature concerning the sorption of phenol by solid adsorbents. At present, polymeric sorbents are widely employed for the isolation and purification of organic [5] and inorganic [6] pollutants. Among the adsorbents used in adsorption technology, copolymers of divinylbenzene are of great importance [7]. Solid phase extraction is now a widely used method for the treatment of effuent water contaminated with organic pollutants [8]. The sorption ability of the different sorbents is strongly dependent on the degree of the hydrophobic nature of the polymer and of the solute to be collected.

Author's address: ${ }^{1}$ University of Belgrade, Faculty of Physical Chemistry, Studentski trg 12-16, Belgrade, Serbia, ${ }^{2}$ University of Belgrade, Faculty of Agriculture, Nemanjina 6, Zemun, Serbia, ${ }^{3}$ University of Belgrade, Institute of Chemistry, Technology and Metallurgy, Njegoševa 12, Belgrade, Serbia

Paper received: 3. 03. 2015.

Paper accepted: 26. 04. 2015.
Wastewater treatment using activated carbon is one of the most important uses of activated carbon. The use of activated carbon as an adsorbent for industrial wastewater treatment is capital-intensive and has several other problems, such as regeneration of activated carbon, intraparticle resistence in adsorption processes in practice, and higt cost of manufacture. However, it is well known that regeneration of active carbon is complicated and expensive. Results about possible applications of zeolites for phenol [2] can be found in the literature.

In the present work, the sorption of phenol from water by a macroporous copolymers was studied by determination of adsorption isotherms. A comparison of the sorption properties of the syntethized macroporous copolymers and activated carbon toward phenol is the aim of this work. The phenol adsorption capacity was found to depend on the hydrophobicity of the adsorbent. An important property of these materials is that to be easily regenerated while keeping there initial properties. The initial and final phenol concentration in aqueous solution after equlibrium were determined using high pressure liquid chromatography (HPLC).

\section{EXPERIMENTAL PART}

\subsection{Materials}

The used activated carbon was of pure quality (Sigma-Aldrich). Macroporous copolymer, poly(glycidyl metacrylate-co-ethylene glycol dimethacylate), i.e. PGME, particle size $0.30-0.15 \mathrm{~mm}$, was sinthetysed, and also modified by ethylene diamine, i.e. PGME-en. Phenol used in this work was of analytical grade of purity (Sigma-Aldrich). The solutions were prepared in deionized water, $\mathrm{pH}$ 6.5. 


\subsection{Synthesis of macroporous polymers}

Two samples of macroporous crosslinked copolymer PGME were prepared by radical suspension copolymerization. Water, monomer phase (containing monomer mixture of glycidyl methacrylate (GMA) and ethylene glycol dimethacrylate, EGDMA, in the ratio 60:40 w/w) and inert component (cyclohexanol and 1-tetradecanol, in the ratio 20:80 v/v) were put into reactor vessel. An amount $(0.3 \mathrm{~g})$ of initiator (2,2'-azobisiso-butyronitrile) was also added. The copolymerization were carried out during 2 hours at $70^{\circ} \mathrm{C}$, and after that for next 2 hours at $85^{\circ} \mathrm{C}\left(\mathrm{PGME}_{1}\right)$ or for 6 hous at $80^{\circ} \mathrm{C}\left(\mathrm{PGME}_{2}\right)$.

The polymer products were separated from water phase, washed by ethanol and dried in vacuum at $40^{\circ} \mathrm{C}$, to constant mass. The resulting crosslinked beads were sieved and the fraction with average particle diameter in the range $0.15-0.30 \mathrm{~mm}$ was used in subsequent reactions and analysis.

\subsection{Funcionalization of macroporous polymers}

A mixture of $4 \mathrm{~g}$ of $\mathrm{PGME}_{1}$ or $\mathrm{PGME}_{2}$ (with particle size from 150 to $300 \mathrm{~m}$ ), $10 \mathrm{~g}$ of ethylene diamine, and $150 \mathrm{~mL}$ of toluene was left at room temperature for $24 \mathrm{~h}$ and then heated $8 \mathrm{~h}$ at $80^{\circ} \mathrm{C}$ at a stiring rate of $125 \mathrm{rpm}$. The modified samples,

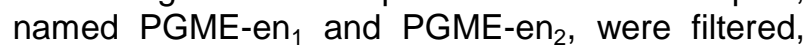
washed with ethanol and dried at $40^{\circ} \mathrm{C}$.

\subsection{Characterization of polymer}

The porosity measurements were made by a mercury instruction porosimeter (Carlo Erba, model 2000) operating in the range $0.1-200 \mathrm{MPa}$. The sample are prepared by drying at $50{ }^{\circ} \mathrm{C}$ during 8 hours and consequent degassing at room temperatue and pressure of $0.5 \mathrm{kPa}$.

The copolymer samples were analyzed for their carbon, hydrogen and nitrogen content using Vario EL III device (GmbH Hanau Instruments, Germany). The content of amino groups was determined by 10 -hours reaction of polymer with $\mathrm{HCl}$ standard solution and consequente titration of supernatant solution with $\mathrm{NaOH}$ standard solution.

The FTIR spectra of polymers were recorded using Perkin-Elmer FT-IR 1725X spectrofotometer in the range $4000-400 \mathrm{~cm}^{-1}$.

\subsection{High pressure liquid chromatography}

All phenol standards and samples were analyzed using HPLC isocratic system (Bischoff, Germany). The C-18 Pronto Sil column (125x4,6 $\mathrm{mm}$ ) was used for isocratic elution and separation with 25:74:1 (v/v/v) methanol/ wather/ acetic acid eluent at a flow rate of $1 \mathrm{~mL} \mathrm{~min}^{-1}$. Detection was performed with an UV detector set at $270 \mathrm{~nm}$. Samples were filtered through a $0.45 \mathrm{~m}$ membrane filter and than $20 \mu \mathrm{L}$ of the sample was injected. Under the given condition, the retention time of phenol peak was $4.85 \mathrm{~min}$. The integrated peak area was plotted against the concentration of the solution and the calibration curves were fitted using linear regression.

\subsection{Procedure of adsorption measurements and calcultations}

Adsorption isotherms examine how adsorbat interacts with adsorbent and how adsorption uptakes vary with adsorbate concentrations at given experimental conditions. Three adsorptions isotherm models: the Langmuir, the Freundlich and the Langmuir-Freundlich (also named "Sips'") models are commonly used to fit the experimental isotherm adsorption data.

The Langmuir isotherm model assumes monolayer adsorption with equal energy and enthalpy for all adsorption sites and takes the form given below:

$$
S_{e}=\frac{K_{L} S_{m} c_{e q}}{1+K_{L} c_{e q}}
$$

Where: $c_{e q}$ is the concentration of solution at equilibrium $\left(\mathrm{mol} \mathrm{dm}^{-3}\right), S_{e}$ is the amount of adsorbate bonded to adsorbent in the case of reached equilibrium ( $\left.\mathrm{mol} \mathrm{g}^{-1}\right), S_{m}$ is the maximum amount of adsorbate bonded to adsobent when a monolayer is formed $\left(\mathrm{mol} \mathrm{g}^{-1}\right)$, and $K_{L}$ is the adsorption intensity or Langmuir coefficient $\left(\mathrm{dm}^{3} \mathrm{~mol}^{-1}\right)$. The basic assumption of Langmuir's theory is that the adsorption of one single adsorbate molecule takes place at specific active sites of an energetically homogeneous surface of the adsorbent.

By, contrast the Freundlich isotherm is an experimental model that can be applied to nonideal adsorption on heterogeneous surface as well as for multi-layer adsorption, it has been derived by assuming the heterogenity of surface (exponentially decaying adsorption sites strength). It is expressed by the following equation:

$$
S_{e}=K_{F} c_{e q}^{n}
$$

Where: $c_{e q}$ and $S_{e}$ have the same meaning as previously, while $K_{F}\left(\mathrm{~mol} \mathrm{~g}^{-1}\right)\left(\mathrm{mol}^{-1} \mathrm{dm}^{3}\right)^{\mathrm{n}}$ and $n$ are constant in Freundlich isotherm.

Both Langmuir and Freundlich concept are combined in the postulation of "Sips' equation", interaction of one adsorbate molecule with one active site at heterogeneous surface possessing definite number of active sites is presumed [2]. This equation can be expressed as:

$$
S_{e}=\frac{K S_{m} c_{e q}^{n}}{1+K c_{e q}^{n}}
$$

$K$ is constant in Sips' isotherm $\left(\mathrm{dm}^{3} \mathrm{~mol}^{-1}\right)^{n}$. 
The isotherms obtained in this study were interpreted using different models, in each case the isotherm parameters were determined by fitting, using Origin 8 software. Parameters of the adsorption isotherms of polymers have been calculated and compared with the data reached by using activated carbon as adsorbent.

Adsorption iosotherm for phenol on copolymers and functionalized copolymers were obtained using the batch equilibrium technique.

To $50 \mathrm{~cm}^{3}$ of phenol solution $1.0000 \mathrm{~g}$ of adsorbent was added and suspension was shaken for $120 \mathrm{~min}$. The initial phenol concentrations were: $0.00025,0.0005,0.001,0.002,0.004,0.005,0.01$, $0.0125,0.015$ and $0.02 \mathrm{~mol} \mathrm{dm}^{-3}$. When shaking was done, suspensions were centrifuged at 10000 rpm for $15 \mathrm{~min}$. The amount of phenol adsorbed by copolymer $\left(\mathrm{mol} \mathrm{g}^{-1}\right)$ was calculed as difference between initial phenol concentration and that remaining in equlibrium solution $\left(\mathrm{mol} \mathrm{dm}^{-3}\right)$. Each point of the obtained adsorption isotherms was determined in a separate experiment.

Finnaly, the obtained results were expresed in the form of adsorptions isotherms: the amount of adsorbed phenol (per $1 \mathrm{~g}$ of adsorbent) as a function of the phenol amount remaining in the equlibrium solution, at $293 \mathrm{~K}$.

\section{RESULTS AND DISCUSSION}

\subsection{Porosity characterization of polymers}

Porosity of PGME and PGME-en samples was characterized by mercury porosimetry. The mercury instruction allowed to describe the macro and mesopore structure, which affects the adsorption kinetics. The specific surface area $\mathrm{S}_{\mathrm{s}, \mathrm{Hg}}$, specific pore volume, $\mathrm{V}_{\mathrm{s}}$, pore diameter, which corresponds to the half of pore volume, $d_{v / 2}$, are presented in table 1.

Table 1- Porosity parameters of the initial and funcionalized PGME samples

\begin{tabular}{ccccc}
\hline Uzorak & $\begin{array}{c}\mathrm{S}_{\mathrm{s}, \mathrm{Hg}} \\
\left(\mathrm{m}^{2} / \mathrm{g}\right)\end{array}$ & $\begin{array}{c}\mathrm{V}_{\mathrm{s}} \\
\left(\mathrm{cm}^{3} / \mathrm{g}\right)\end{array}$ & $\begin{array}{c}\mathrm{d}_{\mathrm{V} / 2} \\
(\mathrm{~nm})\end{array}$ & $\begin{array}{c}\text { Porosity } \\
(\%)\end{array}$ \\
\hline PGME $_{1}$ & 27.6 & 0.660 & 270 & 56.0 \\
PGME $_{2}$ & 64.3 & 0.894 & 93 & 48.3 \\
$\begin{array}{c}\text { PGME- } \\
\text { en }\end{array}$ & 46.6 & 1.080 & 132 & 61.4 \\
$\begin{array}{c}\text { PGME- } \\
\text { en }\end{array}$ & 74.6 & 0.919 & 87 & 53.3 \\
\hline
\end{tabular}

The results from Table 1 indicated that aminofuncionalization leads to: a) increase of specific surface area $(69 \%$ for PGME-en 1 and $16 \%$ for PGME-en 2$)$; b) increase of specific pore volume (64\% for PGME-en P $_{1}$ and $3 \%$ for PGME-en $)$; c) decrease of pore diameter ( $51 \%$ for PGME-en 1 and
$6 \%$ for PGME-en 2 ); and, d) increase of porosity for both funcionalized copolymers for aproximetly $10 \%$.

\subsection{The amino groups content analysis}

The content of amino groups (given as $\% \mathrm{~N}$ ) for each sample was determined by elemental analysis. The introduction of amino groups in the polymer can be achieved by reacting the epoxide groups with different reagents as the source of amino groups, and thus the amino-funcionalization reaction varies depending on the reagent. Sample PGME-en ${ }_{2}$ had the higher nitrogen content, Table 2.

Table 2 - Elemental analysis of the investigated polymers

\begin{tabular}{ccccc}
\hline Polymer & $\mathrm{N}(\%)$ & $\mathrm{C}(\%)$ & $\mathrm{H}(\%)$ & $\mathrm{O}(\%)$ \\
\hline PGME $_{1}$ & - & 60.69 & 7.45 & 31.86 \\
PGME $_{2}$ & - & 59.40 & 7.56 & 33.04 \\
$\begin{array}{c}\text { PGME- } \\
\text { en }\end{array}$ & 6.82 & 52.91 & 7.89 & 32.38 \\
$\begin{array}{c}\text { PGME- } \\
\text { en }\end{array}$ & 8.53 & 50.54 & 7.56 & 33.37 \\
\hline
\end{tabular}

The content of amino groups on functionalyzed polymers was also determined by reaction with $\mathrm{HCl}$ and retitration of supernatant with $\mathrm{NaOH}$. The analysis indicated the amino content of $5.39 \mathrm{mmol}$ $\mathrm{g}^{-1}$ (PGME-en $)$ and $5.86 \mathrm{mmol} \mathrm{g}^{-1}$ (PGME-en ${ }_{2}$. The nonfunctionalyzed polymers samples, $\mathrm{PGME}_{1}$ and $\mathrm{PGME}_{2}$ did not react with $\mathrm{HCl}$, because there is no amino grups in their composition.

\subsection{FTIR characterization of polymers}

Figures 1 and 2 show the FTIR spectra, of the initial and the amino-functionalized samples, respectively. The assignment of bands to specific chemical bonds is given in Table 3 .

The IR measurements data clearly show the presence of both epoxy group and ester carbonyl group in the unmodified copolymers and also the amino group in the modified copolymers. The presence of epoxy group shows that glycidyl methacrylate has been incorporated into the copolymer chain. The bands at $2947.4 \mathrm{~cm}^{-1}$ are due to the stretching vibration (v) of $\mathrm{C}-\mathrm{H}$ bond, the strong bands at 1144.1 are due to the stretching vibration of the $\mathrm{C}-\mathrm{O}$ ester bond, and the strong bands at 1724.1 are due to the stretching vibration of the $>\mathrm{C}=\mathrm{O}$.

The bands characteristic for crosslinked copolymer were not changed in the modified sample, with the exception of the intensity of the epoxy group vibration, which indicate that the structure of the copolymer remains unchanged in the process of modification with ethylene diamine. 


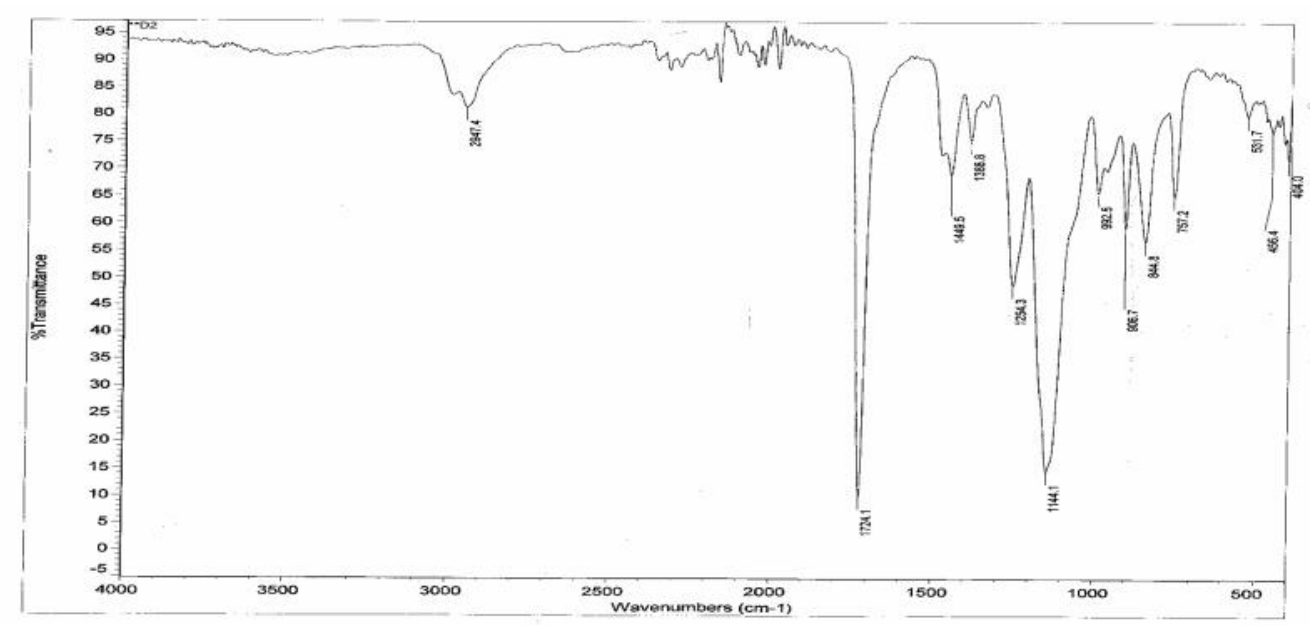

Figure 1 - FTIR spectrum of PGME copolymer

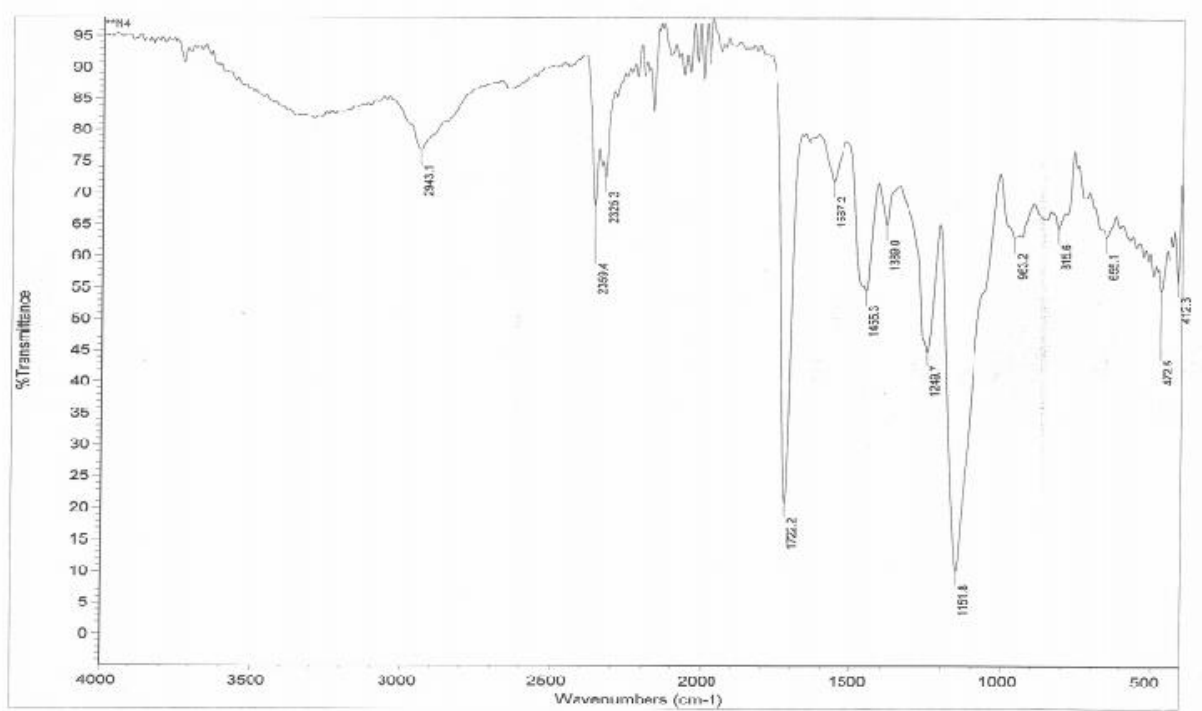

Figure 2- FTIR spectrum of PGME-en copolymer

Table 3 - FTIR Spectra Assignments

\begin{tabular}{|c|c|c|c|c|c|c|c|}
\hline \multirow{2}{*}{ Sample } & \multirow{2}{*}{\multicolumn{2}{|c|}{ Epoxide ring vibration $\left(\mathrm{cm}^{-1}\right)$}} & \multicolumn{3}{|c|}{ Crosslinked copolymers vibration $\left(\mathrm{cm}^{-1}\right)$} & \multirow{2}{*}{$\begin{array}{l}\delta\left(\mathrm{NH}^{-1}\right) \\
\left(\mathrm{cm}^{-1}\right)\end{array}$} & \multirow{2}{*}{$\begin{array}{l}\mathrm{v}(\mathrm{NH}) \\
\left(\mathrm{cm}^{-1}\right)\end{array}$} \\
\hline & & & $\mathrm{v}(\mathrm{CH})$ & $\mathrm{v}(\mathrm{CO})$ & $\mathrm{v}(>\mathrm{C}=\mathrm{O})$ & & \\
\hline PGME & 906.7 & 844.8 & 2947.4 & 1144.1 & 1724.1 & & \\
\hline PGME-en & & 815.6 & 2943.1 & 1151.8 & 1722.2 & 1567.2 & 1389.0 \\
\hline
\end{tabular}

The bands due to the epoxide ring vibration at 906.7 and $844.8 \mathrm{~cm}^{-1}$ in the spectrum of PGME have not completely disappeared in the spectrum of modified sample PGME-en, although their intensity became very small, and they were shifted to smaller frequencies (from 844.8 to 815.6). The band in the spectrum of PGME at $906.7 \mathrm{~cm}^{-1}$ disappeared entirely in the spectrum PGME-en. The result of the conversion of epoxy group is the appearance of new bands at 1567.2 and $1389 \mathrm{~cm}^{-1}$ (PGME-en) in the spectra of amino-functionalized copolymers, due to the presence of amino group and its bending, $\delta(\mathrm{NH})$, and stretching vibration, $\mathrm{v}(\mathrm{NH})$.

\subsection{The results of adsorption measurements}

The isotherms for phenol adsorption by copolymers, obtained by ploting the amount of phenol adsorbed per unit of weigth of adsorbent, against the equlibrium concentration of phenol in solution, is presented in Figure 3. In all presented isotherms, the number of moles adsorbed per gram of copolymer is denoted as $\mathrm{N}_{a}$; while the concentraton of adsorbate determined at equlibrium is denoted as $c_{\text {eq. }}$. It can be seen that the amount of phenol adsorbed increases with increasing the phenol concentration and the adsorption followed a nonlinear type of isotherm. 


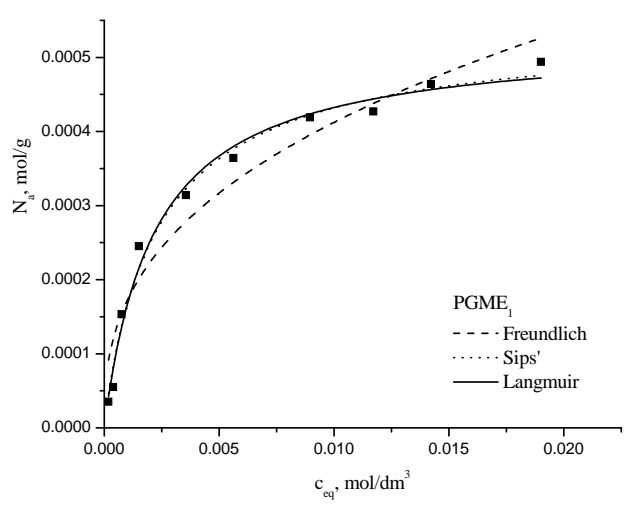

Based on the correlation coefficients, $R^{2}$ the applicabilites of different isotherm equations were compared. The best fit of experimental data obtained using the Langmuir model, having a $R^{2}$ value from 0.9864 for $\mathrm{PGME}_{1}$ to 0.9961 for PGME-en 2 , Table 4. From the same Table, it can be seen that the amino groups quantity affect the adsorption capacity of the polymers which is given as $S_{m}$ value.

The highest adsorption capacity showed polymer PGME-en $2\left(S_{m}=2.03 \mathrm{mmol} \mathrm{dm}{ }^{-3}=191 \mathrm{mg}\right.$ phenol per $1 \mathrm{~g}$ of polymer) which is $43 \%$ of activated carbon adsorption capacity. This polymer also has the highest content of nitrogen $(8.53 \%$, Table 2) and amino-groups (5.86 mmol g $\mathrm{mm}^{-1}$ ), and

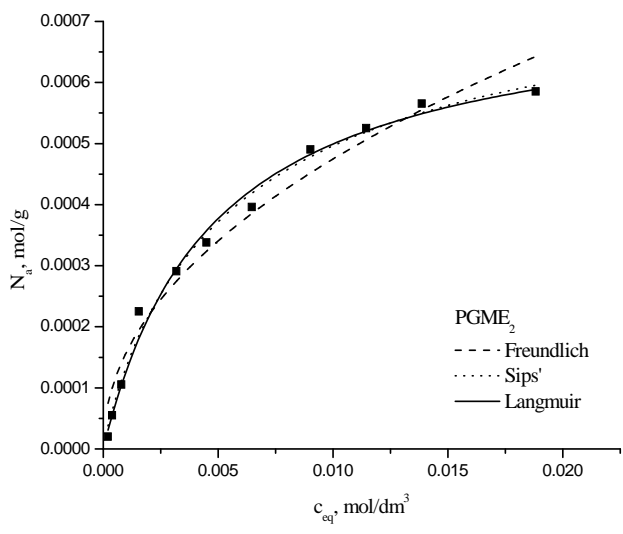
also, as can be seen from Table 1, the highest specific surface area and the smallest pore diameter.

The adsorption of phenol solutions on activated carbons has been widely investigated and it was well established that it involves the formation of electron donor-acceptor complexes where the basic surface oxygen and/or carbon surface electron rich regions act as donors and the aromatic ring of the adsorbate serves as acceptor. Experimantaly obtained isotherms of phenol adsorption on activated carbon are presented on Figure 4.

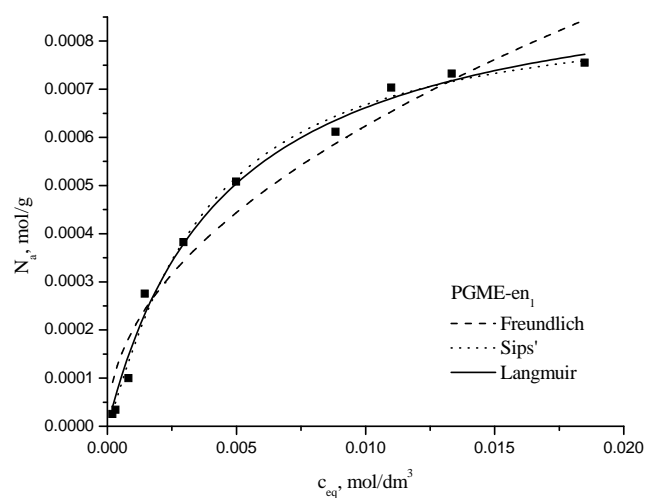

b)
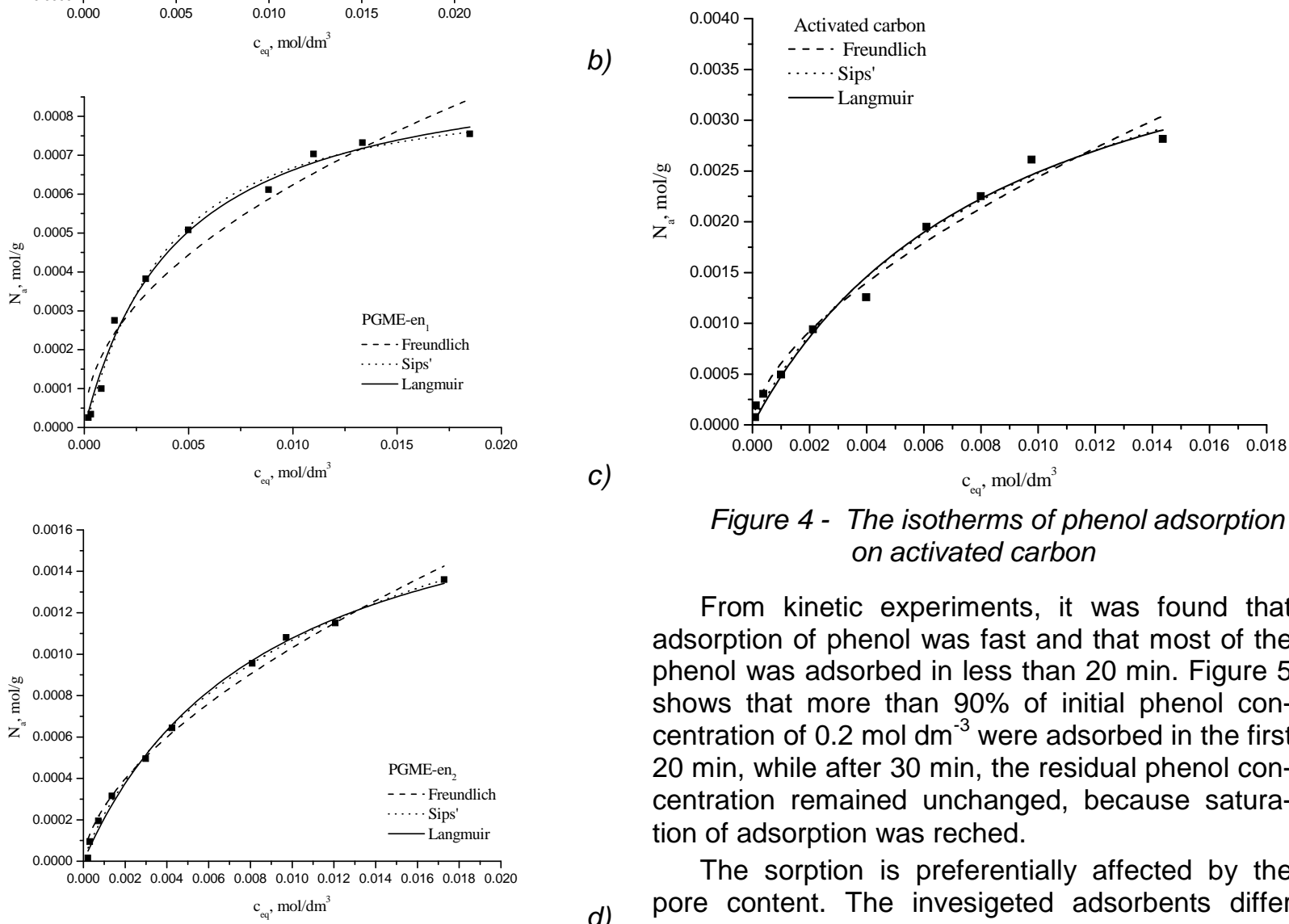

Figure 4 - The isotherms of phenol adsorption on activated carbon

From kinetic experiments, it was found that adsorption of phenol was fast and that most of the phenol was adsorbed in less than $20 \mathrm{~min}$. Figure 5 shows that more than $90 \%$ of initial phenol concentration of $0.2 \mathrm{~mol} \mathrm{dm}^{-3}$ were adsorbed in the first $20 \mathrm{~min}$, while after $30 \mathrm{~min}$, the residual phenol concentration remained unchanged, because saturation of adsorption was reched.

The sorption is preferentially affected by the pore content. The invesigeted adsorbents differ substancialy in sorption activity even at low adsorbate concentrations. Sorbent with the higher values of specific surface areas PGME-en ${ }_{2}$, which also have a higher content of pores exhibit higher sorption activity in comparation with sorbent $\mathrm{PGME}_{1}$.

Figure 3 - The experimentaly obtained isotherms of phenol adsorption using Langmuir, Freundlich and Sips model: a) PGME $E_{1}$; b) PGME $E_{2}$; c) PGME-en ; d) $P G M E-e n_{2}$ 
Table 4 - Isotherms constant for phenol adsorption onto activated carbon, PGME and PGME-en samples

\begin{tabular}{|l|c|c|c|c|c|}
\hline & PGME $_{1}$ & PGME & PGME-en & PGME-en & $\begin{array}{c}\text { Activated } \\
\text { Carbon }\end{array}$ \\
\hline \multicolumn{5}{|c|}{ Sips equation } \\
\hline $\mathrm{S}_{\mathrm{m}}\left(\mathrm{mol} \mathrm{g}^{-1}\right)$ & 0.000542 & 0.000805 & 0.000876 & 0.00245 & 0.00536 \\
$\mathrm{~K}\left(\mathrm{dm}^{3} \mathrm{~mol}^{-1}\right)^{\mathrm{n}}$ & 299.502 & 102.519 & 642.098 & 44.049 & 57.948 \\
$\mathrm{n}$ & 0.94279 & 0.9025 & 1.15154 & 0.87879 & 0.91393 \\
$\mathrm{R}^{2}$ & 0.98488 & 0.99025 & 0.99042 & 0.99681 & 0.98714 \\
\hline \multicolumn{5}{|c|}{ Langmuir equation } \\
\hline $\mathrm{S}_{\mathrm{m}}\left(\mathrm{mol} \mathrm{g}^{-1}\right)$ & 0.000738 & 0.000962 & 0.00203 & 0.0047 \\
$\mathrm{~K}_{\mathrm{L}}\left(\mathrm{dm}^{3} \mathrm{~mol}^{-1}\right)$ & 0.000526 & 208.924 & 220.199 & 113.488 & 0.98835 \\
$\mathrm{R}^{2}$ & 461.205 & 0.99039 & 0.99004 & 0.9961 & 0.98835 \\
\hline \multicolumn{7}{|c|}{ Freundlich equation } \\
\hline $\mathrm{K}_{\mathrm{F}}\left(\mathrm{mol} \mathrm{g}^{-1}\right)\left(\mathrm{mol}^{-1} \mathrm{dm}^{3}\right)^{\mathrm{n}}$ & 0.98644 & 0.0043 & 0.00599 & 0.01581 & 0.03972 \\
$\mathrm{n}$ & 0.00237 & 0.47834 & 0.49104 & 0.59277 & 0.60574 \\
$\mathrm{R}^{2}$ & 0.94033 & 0.96568 & 0.94728 & 0.98825 & 0.98095 \\
\hline
\end{tabular}

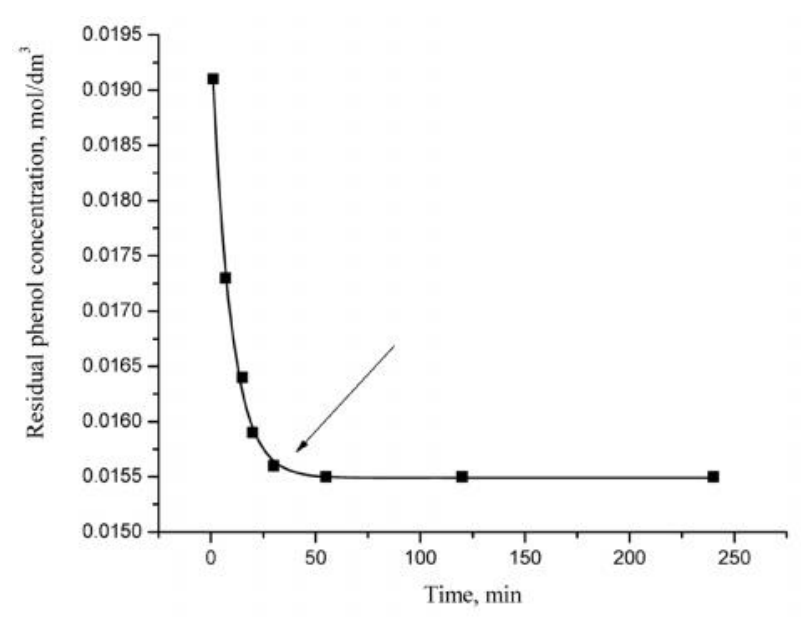

Figure 5 - Residual phenol concentration versus time

\subsection{Mechanism of interaction}

The experimental results established the physical adsorption of phenol on copolymers, which is of course understandable, but also same polar interactions can be expected. The last result can be explained by the concerrence effect of water. The polar ethylene dimethacrylate copolimer is rather a hydrophobic material in comparison with water.

It can be said, that the adsorption of phenols on polymers is mainly affected by porous structure of the adsorbent. The chemical composition of the polymeric adsorbent (presence and quantity of amino groups) plays also role in the adsorbateadsorbent interaction. The physical adsorption by the nonspecific hydrophobic interaction is the binding mechanism of adsorbate on polymeric adsorbents under investigation.

\section{CONCLUSION}

Two macroporous crosslinked PGME samples were syntetized and amino-functionalyzed. The possibility of phenol removal from aqueous solutions was tested under non-competitive conditions. The equilibrium isotherm study showed the best suitability of Langmuir model for the invesigated system, indicating homogenous distribution of active sites on PGME and PGME-en and monolayer sorption. The more efficient sorbents (such as activated carbon) are more expensive and inappropriate for regeneration. The presented results promote the cited polymers as efficient phenol adsorbent.

\section{REFERENCES}

[1] Busca, G., Berardinelli, S, Resini, C., Arrighi, L., (2008) Technologies for the removal of phenol from fluid streams: a short review of recent developments, Journal of Hazardous Materials, 160, 265-288

[2] Damjanović, Lj., Rakić, V., Rac, V., Stošić, D., Auroux, A., (2010) The investigation of phenol removal from agueous solutions by zeolites as solid adsorbents, Journal of Hazardous Materials, 184, 477-484

[3] Ahmaruzzaman, M., (2008) Adsorption of phenolic compounds on low-cost adsorbants: a review, Advances in Colloid and Interface Science, 143, 4867

[4] Bowman, R.S., (2003) Applications of surfactantmodified zeolites to environmental remediation, Microporous and Mesoporous Materials, 61, 43-56

[5] Vazquez, I., Rodriguez-Iglesias, J., Maranon, E., Castrillon, L., Alvarez, M., (2007) Removal of residual phenols from coke wastewater by adsorption, Journal of Hazardous Materials, 147, 395-400 
[6] Maksin, D.D., Nastasović, A.B., Milutinović-Nikolić, A.D., Suručić, Lj.T., Sandić, Z.P., Hercigonja, R.V., Onjia, A.E., (2012) Equilibrium and kinetics study on hexavalent chromium adsorption onto diethylene triamine grafted glycidyl methacrylate based copolymers, Journal of Hazardous Materials, 209. 210, 99-110
[7] Martel, B., Morcellet, M., (1994) Sorption of aromatic compounds in water using polymer sorbents containing amino groups, Jounal of Applied Polymer Science, 51, 443-451

[8] Azanova, V. V., Hardil, J., (1999) Sorption properties of macroporous and hypercrosslinked copolymers, Reactive and Functional Polymers, 41, 163-175

\section{IZVOD}

\section{ISPITIVANJE ADSORPCIJE FENOLA NA MAKROPOROZNIM POLIMERNIM ADSORBENSIMA}

Ovaj rad se bavi proučavanjem adsorpcije fenola iz vodenih rastvora na kopolimerima različitih poroznih karakteristika i polarnosti. Korišćeni adsorbensi se baziraju na glicidil metakrilatu: dva uzorka makroporoznog poli(glicidil metakrilat-co-etilen glikol dimethakrilat) su sintetisani suspenzionom kopolimerizacijom sa etilen glikol dimetakrilatom. Dodatno, dva kopolimera su funkcionalizovani sa etilen diaminom. Količina adsorbovanog fenola je predstavljena u vidu adsorpcionih izotermi, koje su interpretirane korišćenjem Langmuir-ove, Freundlich-ove i Sips-ove jednačine: prva od ovih daje visok nivo slaganja sa eksperimentalnim podacima. Adsorpcija fenola ukazuje na homogenu raspodelu aktivnih mesta prisutnih u ispitivanim polimernim sistemima. Rezultati dobijeni u ovom istraživanju pokazuju da adsorpcija fenola na ispitivanim kopolimerima zavisi od prisustva amino grupa i od veličine pora. Adsorpcija fenola iz vodenih rastvora je brza u slučaju svih korišćenih adsorbenasa. Na osnovu dobivenih rezultata, može se zaključiti da su makroporozni polimeri materijali čije je adsorpcioni kapacitet za fenol uporediv sa onim koji ima aktivni ugalj.

Ključne reči: fenol, adsorpcija, makroporozni polimeri, kinetika, kapacitet

Originalni naučni rad

Rad primljen: 03. 03. 2015.

Rad prihvaćen: 26. 04. 2015. 